\title{
Wherein lies the debate? Concerning whether God is a person
}

\section{Ben Page ${ }^{1}$ (D)}

Received: 25 June 2018 / Accepted: 13 November 2018 / Published online: 17 November 2018

(C) The Author(s) 2018

\section{Abstract}

Within contemporary philosophy of religion there are three main ways in which God is conceptualised in relation to personhood:

(1) God is a person and so personal (PP).

(2) God is non-personal, and so is not a person (NPNP).

(3) God is a personal non-person (PNP).

The first two of these options will be familiar to many, with (PP) held by most contemporary monotheist philosophers of religion and (NPNP) mainly by those who are pantheists. (PNP), however, is a view some may not have come across, despite its proponents claiming it was the view of great philosophical theologians from the past. However, within recent times (PNP) has become more popular. On the face of it, it might not be clear what the difference between (PP) and (PNP) is, and whether debate had between the two positions is substantive. The goal of this paper is therefore to clarify the debate and assess whether the many claims advocates of (PNP) make as to why God cannot be a person (PP) stand up to scrutiny or are persuasive. My suggestion will be that on the whole they do and are not. As such, defenders of (PNP) will either need to defend these reasons in more detail or focus on the area I suggest the debate really rests on.

Keywords God · Monotheism · Person · Classical theism · Personal · Theistic personalism $\cdot$ Simplicity $\cdot$ Transcendence

Within contemporary philosophy of religion there are three main ways in which God is conceptualised in relation to personhood:

1. God is a person and so personal (PP)

Ben Page

benjamin.t.page@durham.ac.uk

1 University of Durham, Durham, UK 
2. God is non-personal, and so is not a person (NPNP)

3. God is a personal non-person (PNP)

The first two of these options will be familiar to many, with 1 held by most contemporary monotheist philosophers of religion and 2 mainly by those who are pantheists. 3 , however, is a view some may not have come across, despite its proponents claiming it was the view of great philosophical theologians from the past. However, in recent times 3 has become more popular, with its proponents calling it 'classical theism', and naming 1 either 'theistic personalism' or 'monopolytheism'. Perhaps these names are apt, but many will find them pejorative. ${ }^{1}$ As such I use the names for the positions I have given above: (PP), (NPNP), (PNP).

On the face of it, it may not be clear what the debate between (PP) and (PNP) is, and whether it is a substantive one. The goal of this paper is therefore to clarify the debate and assess whether the many claims advocates of (PNP) make as to why God cannot be a person stand up to scrutiny or are persuasive. My suggestion will be that on the whole they do not. As such, defenders of (PNP) will either need to defend these reasons in more detail or focus on the area I suggest the debate really rests on, namely a specific understanding of divine simplicity. Although interesting, (NPNP), will feature very little in the following discussion. ${ }^{2}$

\section{(PP) and (PNP)}

(PP) claims that God is a person. Examples of those who hold this are not difficult to come by:

all theists see God as a person. (Mawson 2005, 14)

Assume (as all perfect being theologians do) that necessarily, someone is God if that person is a perfect being. (Leftow 1990, 590)

That God is a person, yet one without a body, seems the most elementary claim of theism. (Swinburne 2016, 104)

God is a person, at least in the broad sense of an entity possessing the sorts of mental states generally regarded as constitutive of personhood. (Brower 2009, 106)

God is a person; that is, a being with intellect and will. (Plantinga 2000, vii)

Nonetheless, (PP) is not universally held by theists. Some, for instance, hold to (NPNP) and as such claim God is neither a person nor personal. This claim is available to monotheists, with Oppy suggesting those who prefer to call God a 'Principle', 'ground', or the like seem to hold this view $(2014,10)$. Due to this he suggests 'it seems rather implausible to suppose that it is part of the very concept of

\footnotetext{
1 Another reason for adopting different terminology is that some think classical theism asserts that God is a person. 'Classical theism is a personalism: God is a person and we, as made in the image and likeness of God, are also persons.' (Vallicella 2016, 381).

2 There has been some interesting recent discussion which explores this: (Buckareff and Nagasawa 2016a).
} 
monotheism that God is personal in nature.' $(2014,10)$ Defenders of $(\mathrm{PNP})^{3}$ will likely want to resist this conclusion, since they assert God is personal, with Feser writing, 'what distinguishes ... [(PP) from (PNP)] is not that it regards God as personal as opposed to impersonal. Since most classical theists attribute intellect and will to God, they too generally regard God as personal.' (2017, 190; Pouivet 2018, 14) Instead what defenders of (PNP) deny is that God has the necessary characteristics to be considered a person. As such they would instead agree with something else Oppy says when he writes, 'At the very least, it is clear that there are many in the Christian tradition who have wanted to resist the suggestion that God is literally a person.' $(2014,10, \mathrm{n} .3)$

Whilst it might seem that (PNP) is a novel thesis, its defenders appeal to history, claiming this view of God is in fact the traditional one and that (PP) is the more modern. ${ }^{4}$ For instance, Davies $(2006,59)$ suggests that the first occurrence of (PP) in English came in 1644 when John Biddle was charged with heresy for defending Unitarian beliefs about God. ${ }^{5}$ Further, it is also proposed that many famous philosophers of religion of the past would also have denied (PP) for (PNP), with Buckareff and Nagaswa claiming that 'If the progenitors of classical theism are taken to be the likes of Anselm, Ibn Rushd, Maimonides, and Thomas Aquinas, then it is not clear that they literally took God to be a person.' $(2016 \mathrm{~b}, 1, \mathrm{n} .1)^{6}$ Obviously for these claims to withstand scrutiny more evidence for them would need to be provided, and further it would need to be shown that defenders of (PP) mean the same by 'person' as what these figures of history meant. Davies certainly seems to think such can be argued in Aquinas's case (2011, 125-126), with Aquinas perhaps being the main poster boy for those defending (PNP) today. This, though, might be a mistake, since in at least one place, when referring to the word person, Aquinas writes, 'yet that which the word signifies, namely that which subsists in an intellectual nature, is appropriate to God; and for this reason, the term person is properly ascribed to God.' (De Potentia Dei, q.9, a.3, co.) As such, at the very least it looks like Aquinas is asserting (PP) here. Despite this, for the purpose of this paper whether (PP) is a recent development is neither here nor there. Rather what is important is to clarify why defenders of (PNP) think God cannot be a person and assessing whether these reasons are any good.

Before delving into this, however, we must first ascertain what is meant by 'person' and what is meant by 'personal', so to work out what (PNP) denies and affirms, and it is to this we now turn.

\footnotetext{
${ }^{3}$ The main proponents of this view are Davies (2004, 2006, 2011), Feser (2009, 2013, 2017), Bently Hart (2013), Pouivet (2018), Hewitt (2018), and Thatcher (1985). I note here that not all are Thomists, for instance Hart, although all are heavily invested in ancient and medieval thought about God. However, whilst some proponents of (PP) may not be as invested in this tradition, many others are such as Brian Leftow, Jeffrey Brower, Eleanor Stump and Alexandre Pruss. Given this, classifying this as debate between Thomists and others isn't as clear cut as some would suggest.

${ }^{4}$ Interestingly one reader of this paper has suggested to me that they think God being a non-personal person (NPP) is in fact the 'traditional view'. However, since this hasn't been defended anywhere at present, as far as I can tell, I leave this for others to investigate.

${ }^{5}$ Webb seems to agree with the assessment that calling God a person, (PP), is fairly recent: (Webb 1919, $61-88)$.

${ }^{6}$ More modern theologians, such as Tillich $(1955,13,16,24-26,33-34,59,74,82-84)$ and others (Thatcher 1985, 71-73) also seem to deny (PP) for (PNP).
} 


\section{Person and personal}

Before setting out how I think we should answer this question, given what defenders of (PP) have said, let me first lay out what those who defend (PNP) think (PP)'s conception of persons is. In short, Cartesian souls. For instance, Davies writes, 'Generally, theistic personalists take God to be strikingly similar to what Descartes describes himself as being when explaining what he thinks he is.' $(2004,11 ; 2011,80,126$; Pouivet 2018, 3) The proponent of (PP) Davies seems to have in mind when making this comment is Swinburne, since elsewhere he writes,

Like many philosophers, especially since the time of Rene Descartes (15961650), Swinburne thinks that people (persons) are composed of two kinds of stuff - mental, incorporeal, indivisible stuff (mind) and physical, extended, divisible stuff (body). On this account, the real me is my mind (or soul), and so I, like all persons, am essentially incorporeal. I am causally connected to what is material, but I am not myself a material thing. I am a spirit. And, so Swinburne thinks, this is what God is - a 'person without a body'. $(2006,52)$

Davies has a number of worries about this view of persons when applied to God, most of which I will look at in the rest of the paper, but for now I focus on one, namely that he doesn't think persons are purely immaterial beings.

Taking a hylomorphic view on human constitution, Davies $(2006,61,2011,126)^{7}$ thinks persons are essentially bodied beings and as such purely immaterial persons are impossible. The thought is spelled out more fully by Feser, when he claims that it is only body and soul (the immaterial aspect) that jointly constitute a person, and as such 'the persistence of the soul after death does not amount to the survival of the person; when John dies, his soul carries on, but he does not, at least not strictly speaking. What the soul's survival does do, however, is make it possible for the person to live again.' $(2009,161)$ Immaterial souls, then, are not persons. However, although this may be a view some hylomorphists take, it isn't the only one, since Oderberg (2007, 257), a fellow hylomorphist, seems to think that the disembodied soul of a human can still be a person since it was once embodied. ${ }^{8}$ What Oderberg objects to is the thought that a human person can be disembodied throughout its whole history, since he thinks humans are essentially embodied beings. But this fact doesn't lead him to think that there couldn't have been other types of persons which were never embodied. Oderberg seems open to thinking there could have been, 'but it would not be a disembodied human person because human persons are just not that kind of thing.' $(2007,257)$ The defender of (PP) is likely to agree with Oderberg here and suggest God is a type of person that is never embodied. As such, I suggest this reason

\footnotetext{
7 Note that the version of hylomorphism Davies holds about human persons is the traditional one, following Aquinas and perhaps Aristotle. This differs from many modern construals, such as Jaworski's (2016).

8 This is largely the debate between survivalism and corruptionism.
} 
for rejecting (PP), based on a hylomorphic conception of persons isn't particularly strong. One could either reject the hylomorphism within the argument, or show how versions of hylomorphism, such as Oderberg's, overcome it. However, a further point needs to be made here too, in that many proponents of (PP), perhaps most, do not mean by person a Cartesian soul, and so wedding (PP) to this account seems unfair. ${ }^{9}$ Rather it appears what most proponents of (PP) mean by person takes its cue from contemporary ethics. ${ }^{10}$

What constitutes a person has undergone a lot of discussion in ethics, since the answer to this question is thought to have significant implications for debates surrounding the start and end of life. The result of this investigation has been to adopt a criterial approach, such that when a being satisfies the criteria they are deemed a person. ${ }^{11}$ I do not wish to enter into the debate about how these criteria are to be satisfied, but note that even within this discussion it is not the criteria themselves that are questioned, but rather just how they are to be satisfied. ${ }^{12}$ What then are the criteria that are usually given which are thought to confer personhood? Here are a few examples:

(1) consciousness (of objects and events external and/or internal to the being), and in particular the capacity to feel pain;

(2) reasoning (the developed capacity to solve new and relatively complex problems);

(3) self-motivated activity (activity which is relatively independent of either genetic or direct external control);

(4) the capacity to communicate, by whatever means, messages of an indefinite variety of types, that is, not just with an indefinite number of possible contents, but on indefinitely many possible topics;

(5) the presence of self-concepts, and self-awareness, either individual or racial, or both. (Warren 1973, 55)

an entity cannot be a person unless it has developed to the point where it is capable of at least some sort of mental life. (Tooley 1983, 170)

\footnotetext{
9 Davies $(2006,61)$ does seem to concede this, but he does seem quite strongly wedded to the thought that (PP) think of persons in Cartesian terms.

${ }^{10}$ There has also been discussion of what a person is in contemporary philosophy of mind, where the criterial approach has also gained prominence. Further, the criteria given are much the same as those given within contemporary ethics, e.g. see Dennett (1976, 177-178) and Baker (2000, 91), and as such it shouldn't be thought that this way of thinking about persons is confined to one area of philosophy alone, but rather has wide acceptance.

11 Chappell (2011) is someone who argues against this type of approach.

12 Oderberg $(2000,174-184)$ for instance thinks that being in potency to the criteria is enough to satisfy it whilst many others think being in act, or having the property categorically is what is required. Unfortunately, these discussions often do not pay much attention to debates within contemporary metaphysics since the debate between categoricalists and those who accept a realist view of dispositions/powers/ potencies/capacities seems like it may have much to contribute here.
} 
I will use the term "person" to refer to any entity with a mental life of a certain order of complexity and sophistication. (McMahan 2002, 6)

I propose to use 'person', in the sense of a rational and self-aware being (Singer 2011, 74-75)

What is most common among all the definitions is the thought that some fairly sophisticated level of consciousness, self-consciousness, and rationality is required in order to be a person. Further, what is striking is the omission of any language of 'immateriality'. The reason for this, I take it, is that many materialist philosophers wouldn't want to deny that there are persons, and additionally many would want to allow that there could be persons of different types, with some perhaps being material and others not (Baker $2000,92)$. Given this, for the rest of the paper I'm going to assume that two criteria establish personhood, namely having some fairly sophisticated level of consciousness (including self-consciousness) and being rational. ${ }^{13}$ These two conditions seem able to incorporate most of the criteria given above of personhood and therefore shouldn't be seen as ad hoc. Further, and more importantly, criteria such as this, and the criterial approach more generally have been used by advocates of (PP) when they argue that God is a person (Mawson 2005, 12-19, 2019, 16; Craig 1998c, 2001, 77-86). ${ }^{14}$ Given this, those advocating (PNP) should take the majority of (PP) advocates as holding to a criterial view of persons, rather than thinking of persons as Cartesian souls, ${ }^{15}$ and as such it should be the criterial view they primarily aim their concerns at. ${ }^{16}$

Now that I have clarified what is meant by a person I turn to what defenders of (PNP) mean when they say that God is personal. Unfortunately, here I can't do much other than quote the little that has been written on this by them. Pouivet for instance writes, 'there is nothing absurd in saying that God is personal but not a person. ... it is possible for God not to be a person without that meaning He has no intelligence, will, omniscience, freedom and love.' Here we have no explicit definition as to what it means to be personal, but I take Pouivet as suggesting the characteristics of intelligence, will, omniscience, freedom and love to be those which are enough to make a being personal. Similarly, Feser $(2017,190)$ writes, 'Since most classical theists attribute intellect and will to God, they too generally regard God as personal.' Again, in this discussion we are not told whether these characteristics are individually sufficient, or if there are others which may also make a being personal. Nevertheless, given other things held by proponents of (PNP) I take it that we can assume that these

\footnotetext{
${ }^{13}$ Again, here I do not specify how these criteria must be met, for instance two options could be in virtue of having these as categorical properties or due to possessing certain dispositions/powers/potencies/ capacities which might not have yet manifested. This latter view would allow far more things to be considered persons than the former.

${ }^{14}$ Swinburne (2016, 107-108) also appeals to criteria when thinking about God being a person.

15 This is not to say that Cartesianism about the soul is incompatible with these criteria, but rather that it is the criteria doing the work to establish personhood, not the immaterial soul aspect of the Cartesian view.

${ }^{16}$ Obviously, one could adopt a different view of persons and hold to (PP). For instance, van Inwagen thinks God is a person, but is explicit in not providing an analysis of what is meant by person $(2006,20)$. I leave it open for those who advocate (PNP) to try their case against these differing conceptions as to what it means for God to be a person.
} 
characteristics need not imply that God has a personality, or that they are properties of God. Rather they are true predications about God, although analogically true.

It seems to me that defenders of (PNP) would do well to further discuss what they mean when they say God is personal, since it is apt to cause confusion to some, and their position, at least to me and others I have spoken to, is not as clear as it could be. Nevertheless, with the notions of person and personal clarified as to how their proponents think of them and as to how they will be used in the rest of the paper, we can turn to the reasons defenders of (PNP) give for thinking (PP) is mistaken.

\section{Why think God isn't a person?}

There are a number of reasons defenders of (PNP) give to suggest that God cannot be a person, with these mostly being due to conflicts they see arising in the divine nature when one claims (PP) (Feser 2013). ${ }^{17}$ As a result to avoid the conflicts, rather than denying these conflicting attributes of God, it is better, so defenders of (PNP) claim, to deny that He is a person. My aim in the reminder of this paper is to show that these supposed conflicts are far from conclusive and that defenders of (PNP) seem unaware of much of the literature where (PP) is argued to be consistent with the claims that (PNP) supposes it is not. I therefore will suggest that the debate lies only in one area, or defenders of (PNP) will have to show in far greater detail, that there are the incompatibilities they claim.

\section{Trinity-God is three persons}

The first apparent incompatibility is that God isn't a person because He is three persons. Thus, Davies writes, 'According to the doctrine of the Trinity, God is certainly not three persons in one person.' $(2006,59)$ In this he is correct. As a result, a few things need to be said to defend (PP). First, most theists who claim (PP) claim it of theism in general, rather than Christian theism. As such they might suggest that (PP) addresses something more fundamental to theism, rather than Trinitarian concerns. Perhaps the thought is that whatever God is, He is at least one person. However, many of those who claim (PP) also give accounts of the Trinity, and as such I take it that they do not think their two claims inconsistent. ${ }^{18}$ This could be for a number of reasons. One might be that because you can say of every member of the Trinity both 'that is God' and 'that is a person', it seems you can also say that God is a person, and this needn't seem troubling. Another response might be to claim that 'person' when referring to God is meant as a kind concept, but when referring to

\footnotetext{
17 Unfortunately, I am unable to investigate claims which deny God is a person due to linguistic reasons (Hewitt 2018) or that God is neither a person or personal because He does not have a personality (Mander 1997) due to space. Whilst the former might show another place where the debate between (PP) and (PNP) lies, the latter would be detrimental to both (PP) and (PNP).

18 Three people I have in mind, since I quoted them above as holding to (PP), are Leftow (2004a), Swinburne (1994, ch.8), and Brower and Rea (2005).
} 
the members of the Trinity it is not. Thus, assuming all humans are persons, I might say of a group of humans that they are of the kind 'person', whilst also saying they are many persons, since they have instantiated this kind multiple times. As we shall see later, this may cause defenders of (PNP) to have other worries, but it does seem a viable option here. A third response would be to suggest that when we do perfect being theology (PBT) we are merely working out what language is applicable to God (Leftow 2004b, 134), and since it is greater to be a person than not this language is applicable to God. ${ }^{19}$ Even Aquinas seems to think something like this is the case when he writes, 'Then, since whatsoever is most excellent in creatures should be attributed to God, it is fitting that the word person should be attributed to God.' (De Potentia Dei, q.9, a.3, co.) However, so the defender of (PP) can claim, when person is used of the Trinity it is meant to signify something more than this.

Another move would be to assume that person meant what Boethius (Liber de persona et duabus naturis contra Eutychen et Nestorium, ch. 2) took it to mean, namely an individual substance with a rational nature, ${ }^{20}$ and claim that this is true of God but not of the persons of the trinity. ${ }^{21}$ After all, many won't want to say that each of the persons are individual substances, since Trinitarian doctrine claims there is only one substance. ${ }^{22}$ Finally, it is open to the defender of (PP) to suggest that person means something so distinct from what it originally meant when formulating the Trinity ${ }^{23}$ that claiming (PP), using the modern definition of person, cannot be thought to contradict God being three persons, when person in this sense is understood as it was meant originally when termed 'hypostasis'. Given these responses, this doesn't seem a good reason to adopt (PNP).

\section{Worries about starting points and results}

Sometimes the complaint that is raised against (PP) is that it has the wrong starting point and as such gives us the wrong results about God's nature (Pouivet 2018, 6-7). To illustrate this complaint, one can look at an analogous case within Trinitarian theorizing. In Trinitarian debates there are at least two pieces of data everyone wants to explain, that God is one substance and that God is three persons. Following Leftow we can think there are two 'explanatory projects' $(2010,441)$ which undertake the task of explaining this data, Social Trinitarianism (ST) and Latin Trinitarianism (LT). ${ }^{24}$ 'ST takes the three Persons as in some way basic and explains how they constitute or give rise to one God.... [Whereas] LT takes the one God as in some way basic and explains how one God gives rise to three Persons.' (Leftow 2010, 441) In

\footnotetext{
19 For a thorough defence of PBT see Leftow (manuscript).

20 Note that this is not too dissimilar as to how I, and others, define person.

21 I have already quoted Aquinas (De Potentia Dei, q.9, a.3, co. \& ad.1) in support of thinking that person can be attributed to God in this way.

22 Although Swinburne (1994, 180-191, 194, 2018) would be happy to claim that each member of the Trinity is a person in the way Boethius defines them.

23 This is a point that even Davies $(2006,60)$ acknowledges.

${ }^{24}$ Note that not everyone thinks that LT and ST are mere explanatory projects.
} 
explicating the Trinity one embraces one of the two explanatory projects, yet both lead to worries. On ST tritheism looms, whilst on LT modalism beckons. Ultimately how one comes to think of the specifics of the Trinity will largely depend upon which explanatory project they prefer. $^{25}$ Yet it shouldn't be forgotten that both approaches seek to explain the same data. Paralleling this with the debate between (PNP) and (PP) two facts are also claimed about God, that He is ultimate and personal. ${ }^{26}$ Yet there is a difference in how we go about explaining these things. Does one start with the thought that God is ultimate and work to the personal, or work from the personal to get to the ultimate. Feser (2013) suggests that (PNP) takes the former thought, whilst those adopting (PP) take the latter, starting 'with the idea that God is "a person" just as we are persons, only without our corporeal and other limitations' and then working to the claim that God is ultimate. ${ }^{27}$ The question then is as to whose starting point is best, since both try to explain the same data in different ways.

Unsurprisingly defenders of (PNP) are likely to answer that their starting point is best, with this perhaps being justified by certain arguments to God's existence, such as Aquinas's first way, which shows God is pure act. Perhaps God is pure act and this rules Him out from being a person. Defenders of (PNP) would need to explain more fully why this is, since if it is due to implications arising from God being pure act, such as simplicity, timelessness, etc., then it might seem that it is these other attributes of God which contradict simplicity rather than pure act itself, and discussions should focus instead on those attributes. After all, there are many in the literature who think God is simple, timeless, etc. and yet don't seem to think God is pure act. However, if the conception of God as pure act is important and does most of the work, defenders of (PNP) will need to defend how we come to think of God in this way as, for example, the ways of Aquinas which do this are highly contested by theists. ${ }^{28}$

Given these considerations, it seems unlikely to me that defenders of (PNP) will persuade many of their cause in this way, through arguing God is pure act. Instead what I think would be more likely to persuade, is showing that being ultimate is greater than being personal, and hence the proper initial axiological judgement of PBT. ${ }^{29}$ Or by demonstrating that the final conception of God produced by (PNP) is superior to that of (PP) and therefore its initial axiological judgement should be preferred. In regard to the former I think it is difficult to show whether one should prefer being ultimate or being personal as one's initial axiological judgement. At

\footnotetext{
${ }^{25}$ For instance, Leftow (1999) has deep concerns about what ST will produce and as such opts for LT.

${ }^{26}$ I use the term 'personal' in this section, although I have no doubt that most defenders of (PP) would claim that to be personal one must be a person. As such for them being personal is just as good as being a person. However, using the word 'personal' allows me to include defenders of (PNP) into this discussion. 27 We might think Leftow's (2012) book God and Necessity is one such attempt to move from (PP) to the ultimate, since his concern is to show how it is and what it means for God to be source of all and ultimate whilst also being a person.

${ }^{28}$ I make no suggestion here about whether they are right to do so.

29 Some who hold to (PNP) might think PBT is a mistaken way to think about God, perhaps instead opting for what might be called creator theology (Kvanvig 2018). Nevertheless, even if they do opt for this methodology note that some advocates of creator theology still think there is a need and a way to argue that God is a person (Kvanvig 2018, 12-13, 2019). That is, (PNP) doesn't follow automatically from creator theology.
} 
any rate my intuitions leave me undecided as to which should be preferred, and it seems an open question in ontology whether 'person' or 'ultimate' should be taken as more fundamental when working out the categories to which a thing belongs. As such it seems to me that instead of disagreeing on initial judgements, both (PP) and (PNP) should fill out their conception of God, and on the basis of their outcome we see which starting point is to be preferred, similar to what I think often happens in Trinitarian theorizing.

Given all this, although those defending (PNP) may complain about the methodology of (PP), in that they start by conceptualizing God as a person, I'm not sure that this complaint amounts to much other than a statement of personal preference. Instead it seems (PNP) will have more weight in persuading defenders of (PP) that God cannot be a person by filling out their conception of God and showing its superiority and demonstrating the incompatibilities arising from God being a person. ${ }^{30}$ Assessing these supposed incompatibilities will be for the rest of this paper to assess.

\section{Creation and conservation ex nihilo}

Davies writes, 'According to ... [(PNP)], God is primarily the Creator. God is what accounts for there being any world at all. He is causally responsible for the existence of everything other than himself. More specifically, God, for ... [(PNP)], is the one (and the only one) who creates 'from nothing' (ex nihilo in the traditional Latin phrase).' (2004, 2) Davies continues in this vein telling us that God is also the sustaining cause of the universe and all it contains (2004, 3), and that God cannot 'intervene' in His own created order $(2004,4)$. For my part there seems no conflict in saying all these things whilst also saying God is a person as (PP) does. For instance, Quinn $(2006,237)$ says God is a person, yet he also defends continuous creation, the doctrine that God creates and conserves ex nihilo (1983, 1988). He clearly sees no incompatibility here. It matters not a whit that others who hold (PP) disagree with Quinn, and therefore also Davies, about the nature of creation, such as Craig (1998a, b), since the debate here is not due to a problem with God being a person but with problems that are thought internal to the doctrine of creation as Davies and Quinn understand it.

Perhaps instead the real concern is over whether creation is a change or not, since it might be thought God doesn't bring about changes but only creates. ${ }^{31}$ Yet this too seems no obstacle to (PP) and once more defenders of (PP), for instance Leftow (2002, 26-34), also defend this doctrine. Again, there seems to be no incoherence here. Finally, maybe the thought is that on (PNP) 'all history is God's doing, ...

\footnotetext{
${ }^{30}$ Often the supposed incompatibilities seem to arise from the conception of God as pure act, and I note here that filling out this conception of God seems to be a form of PBT, since for Aquinas being in act is to be perfect (Leftow 2015).

${ }^{31}$ Davies $(2004,4)$ makes a brief point of this, but it seems key in Aquinas's (Super Sent., lib.2, d.1, q.1.) thought.
} 
[whilst those who hold to (PP)] more commonly see it only as partly this. Some events, they often say, are not so much caused by God as permitted by him.' (Davies $2004,11)$ Two things can be said in response to this. Firstly, suppose one holds to theological determinism, as many are apt to do, then we might wish to say that no act is permitted by God. Yet this seems entirely consistent with God being conscious and rational, namely (PP). Secondly, even within the tradition of those likely to embrace (PNP) there is also a notion of God permitting things, namely in His permissive will. For as Culpepper writes, 'God is said to permissively will moral evil and suffering as something that remains within the scope of divine wisdom, goodness, and power to redeem. ... Speech about God's permissive will, ..., refers to the will to sustain the existence of fallen creatures, precisely out of love for the goodness that remains in them'. (2009, 86-87) Perhaps the defender of the thought that God never permits anything will want to say that God's permissive will here differs in kind from the type of permission many (PP) theists hold that God allows. Maybe this is so, but it doesn't seem that the fact that God is a person has anything to do with this. Rather one will adopt this doctrine independent of whether thinking God is a person or not. Given this, it seems we once again don't have a good reason to give up (PP).

\section{Transcendence}

The next worry given by defenders of (PNP) is that by holding (PP) one denigrates God's transcendence and makes Him too anthropomorphic (Davies 2011, 120; Oppy 2014, 311; Schellenberg 2016, 173-174). Often this is spelt out by claiming that we shouldn't use language about God univocally, but rather analogously. ${ }^{32}$ Hence, Feser (2013) writes (PP) 'thus arrives at an essentially anthropomorphic conception of God. ... He is not "a person," not because he is less than a person but because he is more than merely a person.' What should the defender of (PP) say about this?

I suggest they continue to say what they have already said, since this seems to me sufficient to rebut this charge. For instance, Mawson writes that God is 'more of a person than any of us could ever hope to be.' $(2005,20,2019,18)$ Leftow suggests that 'If God is a person of an extraordinary sort, He is still a person.' (2016a, 73) Finally, even Swinburne claims that there are some respects in which on his view God is not a person $(2016,105)$, and in a number of places suggests that God is a person only in an analogical sense (1994, 156, 2016, 248). Given this, it doesn't appear that there may be any substantial disagreement between (PNP) and (PP) over this point. If defenders of (PNP) merely mean that 'person' cannot be said of God univocally, then I suggest that most defenders of (PP) would largely agree. Perhaps the thought then from (PNP) is that person is an all or nothing affair, and that as Mander $(1997,402)$ says when discussing God and personality, 'what is simply like

\footnotetext{
${ }^{32}$ However, we should remember that 'Aquinas' theory of analogy tells us that these are really, literally true of God, though the way these properties are realized in God-the sense in which they are true of Him or what it is in God that satisfies these terms' senses-is ultimately beyond us.' (Leftow 2016a, 73).
} 
a person, is not in point of fact a person.' As such given what defenders of (PP) say above, God is not in point of fact a person, and so perhaps defenders of (PNP) are correct in what they say, denying God is a person and calling Him personal instead. It seems to me, however, even if defenders of (PP) were to accept this, that those advocating (PNP) would still think this insufficient. That is, how the word 'person' is predicated of God is not where the real conflict lies. Rather, it is the supposed incompatibilities with other attributes, or implications of them, which is where the rub is. As such transcendence and analogy concerns alone are unlikely to persuade (PNP)s that there is no conflict, particularly since this is already what most (PP)s hold. The debate, then, does not lie here.

\section{God is timelessly eternal and impassible}

Another worry some (PNP)'s give against (PP) is because 'God is impassible.... (1) God cannot be altered by anything a creature does, and (2) God is intrinsically unchangeable.... this idea also suggests that God is outside time.' (Davies 2004, $5)^{33}$ The thought seems to be that a person can be neither of these. This, however, can be questioned. First assume God is outside of time and therefore unchanging. Many who think this have been keen to show how God can be a person and yet both of these things (Leftow 1991, 283-312; Craig 2001, 77-86; Craig 1998c; Mawson 2019, 24-33). I do not repeat their defenses here but suggest that much more work would need to be done to show why they fail and why being outside of time and changeless is incompatible with (PP). I leave this work for those who use this as a reason to affirm (PNP) to undertake.

Turning to impassibility, before commenting on Davies's exact formulation, I note that impassibility is often thought to refer to God's emotional state and its lack of change. Thus, perhaps the thought would be that a person necessarily changes in their emotional states. However, I don't see why anyone ought to think this. Suppose God creates a person for an instant and then annihilates them. This person will have had only one emotional state and yet will have still been a person. Further, imagine Nozick's experience machine where all one ever feels is maximum pleasure, again the emotional state of the person doesn't change and yet they still seem to be a person. Perhaps one would need to argue that persons essentially have the capacity to have changing emotional states, with this perhaps being an essential aspect of consciousness or rationality, but this seems like an extremely difficult sell. Maybe then the worry is that God is not the type of being that can have any emotions or passions, yet persons essentially do. However, those who hold to impassibility and also to (PNP) need not think this. ${ }^{34}$ For instance Weinandy writes of the persons of the

\footnotetext{
33 This passage from Davies comes when he is explicating (PNP), which is contrasted in the work by a later explication of (PP). As such I am taking it that he thinks timelessness and impassibility do not fit easily or are incompatible with (PP), and hence give one a reason to adopt (PNP).

34 I think it is likely that Weinady holds to (PNP), although I am not certain. I think this as he takes God to be pure act, wholly simple, impassible, as defenders of (PNP) do.
} 
Trinity, and hence God, 'they are impassible not because they lack passion, in the sense of being fully loving and completely self-giving, but again precisely for the opposite reason ... [they] cannot become more passionate for they are constituted, and so subsist, as who they are only because they have absolutely given themselves completely to one another in love.' (2000, 119-210) We might be able to go even further and suggest that God also experiences some type of suffering for as Culpepper writes, "This "permissive will" in God is fittingly associated with that form of "suffering" known as the "divine patience," and it is precisely here, in God's permissive will, that God the Creator can be said to suffer, insofar as God suffers the creature's refusal of the goodness of his creative intentions, the refusal of what can be called God's antecedent will for the creation. This is the suffering that Jacques Maritain identified as the eternal “wound" in God.' $(2009,87)^{35}$ As such (PP) doesn't look in trouble here.

On Davies reading of impassibility, that God cannot be altered by anything a creature does, there also appears to be nothing which makes it the case that one cannot think this and yet assert (PP). For perhaps one holds to Calvinism such that nothing external influences God, and yet as far as I can tell nothing in this doctrine seems to suggest that God can't be a person. However, there are likely many who hold (PP) that will not want to say this and will instead hold to a Boethian view (Leftow 1991, 246-266), thinking there is a sense in which God is influenced by His creatures in that His knowledge depends on seeing what the creatures are doing. Yet thinking this, as far as I'm aware, never has anything to do with being able to assert (PP), rather this view is adopted due to perceived difficulties with theological determinism. As a result of all this, I suggest that here we also have no good reason to deny $(\mathrm{PP})$.

\section{God isn't a moral agent}

'You might say that there are moral laws of which any decent God needs to take account - this making God a moral agent. After all, is it not commonly said that God is a person? And are persons not subject to moral laws (or duties, or obligations)? And are not such laws (or duties, or obligations) binding on all personseven divine ones? And does this not mean that God is a moral agent?' (Davies 2006, 93) Yet Davies (2006, 254), and others (Feser 2009, 125-126; Pouivet 2018, 8) who defend (PNP) do not think God is a moral agent subject to moral obligations, and hence God is not, or perhaps cannot, be a person. The first thing to be said in response to this is that it is far from clear that moral agency is essential to the concept of person, certainly the definitions I gave above don't make this connection. Within the literature on persons one sometimes reads claims of the sort that 'Persons are beings capable of valuing their own lives' (Harris 1985, 16-17; Engelhardt 1989, 120), but this hardly suggests that persons essentially have moral

\footnotetext{
${ }^{35}$ I suggest that given this was a move made by the influential Thomist Maritain, and since many who hold (PNP) are Thomists, this can be thought to apply to defenders of (PNP) more generally.
} 
obligations. Further, as we have seen time and again, here too there are theists who claim God is a person and yet also think He has no moral obligations. For as Craig (2012) writes, 'I'm inclined to think that God has no moral obligations whatsoever to fulfill. ${ }^{36}$ Further, Maitzen $(2017,145)$ suggest that anyone who holds to a divine command theory (DCT), what he terms voluntarism, should think God has no obligations. Supposing this was correct, it doesn't seem to me that in virtue of coming to know this, defenders of DCT would stop holding to (PP). In fact, most who claim that God has moral obligations think the only obligations He has are those which He gives Himself, perhaps through making promises (Swinburne 2016, 220-221; Leftow 2013, 81-92). Maybe this too is thought problematic by some of those who assert (PNP) but this once again doesn't seem to have anything to do with God being a person, but rather has to do with what promising entails for God. As such, this also doesn't seem a helpful line for the defender of (PNP) to take.

\section{God has a different type of being than persons}

We come to the penultimate reason given for denying (PP). This reason isn't as clear as it might be, but I reconstruct what I take the worry to be. A key point defenders of (PNP) want to make is that when we speak of God's being, "we are pointing toward something incomprehensibly greater than and qualitatively different from the being of a finite thing.' (Hart 2013, 126) Therefore they believe it is an error to think 'that there must be some likeness between God's being and the being of creatures; God's being is the source of created being, after all, so the latter must reflect the former in some measure. The mistake lies in the failure to recognize that the likeness is one of analogy, not of simple identity.' (Hart 2013, 130) I therefore take it that Hart's concern is, given that he is arguing against (PP) when he says this, that persons are finite things, whilst God is not a finite thing, so God cannot be a person.

So to ascertain whether this worry is a good one, we must first clarify what is meant by different types of being. It is fairly common in ontology to think there is only one type of existence or being; everything that exists, exists in the same way as everything else. Thus, Schaffer $(2009,359)$ can answer that God exists even though Schaffer thinks He is a fictional character, since, for Schaffer, and others, fictions have the same type of existence as anything else that exists. ${ }^{37}$ However, recently there have been some defences of ontological pluralism, which holds that being or existence can be had in different ways. McDaniel, the most prominent defender of this position, makes a distinction between different ways of being, writing, 'substances enjoy a better order of being than modes, existing objects enjoy a higher level of being than non-existent objects, and presences enjoy a greater degree of being than absences.' (2017,4) Employing this framework, I take it that when Hart says God has a different type of being from finite things, he means God has the best

\footnotetext{
36 Other theists, such as Adams, who seem to hold to (PP) (Adams 1999, 156), also claim God doesn't have moral obligations $(1999,158)$.

37 See also: (Sorensen 2015).
} 
order of being, highest level of being, and greatest degree of being. The claim then seems to be that a being like this cannot be a person since all persons we know don't have these types of being.

But why should we think they can't? I can see no reason based on ontological pluralism alone which rules out the existence of persons with different types of being, or the type which we specified God has. ${ }^{38}$ It appears prima facie possible to me that there be a type of person which has the best order, highest level, and greatest degree of being. That is, the category of 'person', as I have defined it above, doesn't appear to rule out infinite persons. If the worry is that God cannot belong to a category, then this will need to be addressed, and I do so below. But in and of itself, God having a different type of being doesn't seem to be problematic, or at least the reason why it is problematic needs to be far more clearly delineated. As such, as with all the other suggestions, I'm far from convinced this is a good reason to deny (PP) and assert (PNP).

\section{Divine simplicity}

The final reason given as to why we ought not to hold (PP) is due to divine simplicity, and it is here I suggest (PNP) has its most promising attack against (PP). ${ }^{39}$ However, many have disputed that a simple God cannot be a person. ${ }^{40}$ In fact the most popular formulation, at present, of divine simplicity, the truth-maker account, seems to have been formulated partly in order to claim that God is a person. The essence of this account is that,

God is identical with the truthmakers for each of the true (intrinsic) predications that can be made about him. Thus, if God is divine, he is identical with that which makes him divine; if he is good, he is identical with that which makes him good; and so on in every other such case. ... this interpretation just amounts to the claim that God is the truthmaker for each of the predications in question. (Brower 2008, 19)

Yet on this account there doesn't seem anything suspect with saying that as God is a person He is identical with that which makes Him a person. Given this God can be a person. Suppose however you don't like this account of simplicity (Leftow 2016b), and instead opt for something like Leftow's Augustinian view where God is thought to be the standard of any attribute He is thought to have. Even though we may have no grasp as to what in God makes this true we can on this view say that there is a

\footnotetext{
38 Leftow (1991, 73-111), for instance, argues that God has the greatest degree of existence, since He is timeless, which seems to affirm some of the things ontological pluralists want to say. But as we have seen he still thinks God is a person.

39 Some defenders of (PP), such as Plantinga (1980, 47, 52-53, 57), also argue that personhood and simplicity are incompatible.

${ }^{40}$ For instance, these defenders of simplicity contend that God is a person: Pruss (2006, 257, 2008), Brower (2008; 2009), Stump and Kretzmann (1985, 378, n.2), and Leftow (2006).
} 
single being which is the standard for the attributes expressed by all non-relational predicates that apply to it without any having universals or tropes as constituents.' (Leftow 2006, 378) Yet on this account it also seems God can be a person, in fact He is the perfect standard of person, and we are persons only insofar as we imitate Him.

Given this, simplicity doesn't seem to automatically rule out God being a person. But perhaps one can say simplicity conflicts in a different way with (PP). Suppose, as some have suggested (Leftow 2016b, 48-55), that if God is simple He cannot have any contingent volitions. As such, God isn't free to create what He has created. Yet it might be claimed that persons are essentially free, and given that God isn't, He can't be a person. This also doesn't seem to be a good reason to deny (PP). For suppose we found out that causal determinism concerning human action was true, I don't think this would change anyone's mind as to whether humans were persons. Further, even if we strengthen this to a Spinozistic necessitarianism it doesn't seem that this should change our mind about whether we are persons, at least not given the way most of the literature thinks about what persons are. As a result, worries concerning simplicity seem avoidable.

However, defenders of (PNP) would likely disagree with this assessment. Instead they would say the problem with (PP) is that it essentially treats God as the unique member of a species falling under the genus person' (Feser 2017, 190), however 'God is not an individual belonging to any kind ... [which can be expressed] by saying that God is entirely simple.' (Davies 2004, 8; Feser 2017, 190-191) In virtue of this 'God is not an individual. He belongs to no kind or sort.' (Davies 2004, 9) What can be said as a response to this on behalf of (PP)?

First, one might suggest that Aquinas, (PNP)'s poster boy, seems to explicitly disagree with this line of reasoning. Thus, he puts an objection forward similar to one defenders of (PNP) pose, writing, 'God is not in a genus: because since he is infinite he cannot be confined within the limits of any genus. Now person signifies something in the genus of substance. Therefore person is not to be applied to God.' (De Potentia Dei, q.9, a.3, obj.3) The reply he then gives is, 'Although God is not in the genus of substance as a species, he belongs to the genus of substance as the principle of the genus.' (De Potentia Dei, q.9, a.3, ad.3) ${ }^{41}$ As a result, he seems to reject (PNP)s' reasoning, and as we have already seen, can therefore say that 'the term person is ascribed to God in its proper sense.' (De Potentia Dei, q.9, a.3, co. $)^{42}$ Defenders of (PNP) could either assert that my reading of Aquinas here is wrong, and offer another interpretation, or suggest that Aquinas is wrong here and stand by their claim. Assuming they don't drop their claim, what can (PP) further say in response?

\footnotetext{
41 This passage shouldn't be thought to contradict what Aquinas says in Summa Theologiae I, q.3, a.5 because they are talking about slightly different things.

42 Even if this is just taken to mean that Aquinas thinks person can properly be ascribed to God analogously, as we have seen above many defenders of (PP) would be happy with this claim.
} 
One thing (PP) might question is whether simplicity ought to give us the result defenders of (PNP) think it should. ${ }^{43}$ Stump (2016, 82-92), for instance, has recently questioned this, arguing that the idea that God is not a being, or individual, is in fact unfaithful to the traditional doctrine. Defenders of (PNP) may, however, also concede this point and say this is what simplicity ought to entail whether or not this was the traditional view. The defender of (PP) will therefore either have to argue against simplicity as (PNP) gives it, or show how the other versions of simplicity given above, which seem compatible with (PP), are consistent with the claims made by defenders of (PNP).

Another option defenders of (PP) might take is by contending that person is not a kind concept, with Leftow suggesting this since the criterial view of personhood 'does not seem able to determine persistence-and distinctness-conditions, as a kind-property should. ... [this] might suggest that person is not really a kind'. $(2012,161)^{44}$ If defenders of (PP) don't take this route then they might instead wish to assert that 'God is metaphysically sui generis, and that there is nothing further to be said about the ontological category to which God belongs.' (Oppy 2014, 103; Leftow 2012, 306-308) Yet this doesn't rule out us saying that certain names are not applicable to Him. Thus, following Anselm, we might assert that all PBT tries to do is find " "names" or "words"- bits of language ... rather than ... properties' (Leftow 2004 b, 134) which properly apply to God, with person being one of them. However, despite this move making it consistent to assert that God is a person when one thinks of simplicity as defenders of (PNP) do, it seems that some who advocate (PP) think predicating person on God does more than give him an appropriate name.

Given this, I imagine defenders of (PP) will be more likely to claim that this view of simplicity isn't required, particularly since they might think it leads to strange assertions such as 'God is not an individual'. I suggest that those defending (PP) will be more content in thinking God, by His nature, is of the type 'deity', and that claiming this shouldn't be seen as detrimental once simplicity is understood in one of the two ways explicated earlier. ${ }^{45}$ Yet, it seems that here we have the best case (PNP) has against (PP), and as such this seems to be where the substantive debate lies. The debate then, is to be focused on the exact nature of simplicity, what it claims and what it doesn't, and the reasons for and against embracing certain construals of it. As we have seen, the other disputes, by contrast, are more readily squared with (PP), and as such, efforts in the debate between (PP) and (PNP) should be directed to where the debate really matters.

\footnotetext{
43 For instance, it is a radical claim that God doesn't fall under any kind and one most philosophers of religion reject. Thus, Leftow can write, 'The only kinds it is plausible to see God as belonging to are particular, substance, spirit, person, and deity.' (2012, 280).

44 Pruss (2017) also suggests that person is not a natural kind. He does this by arguing that God is a person, God is not a member of any natural kind, and therefore person is not a natural kind. This concedes some of what defenders of (PNP) think, whilst also retaining (PP).

45 Perhaps one could eliminate the kind 'deity' in the way Leftow attempts too, claiming 'God is the whole ontology for God is divine. ... Divine is just the way $\mathrm{He}$ is, and we need not in this case reify the way. So all it takes to make it true that God is divine is that He exist.' $(2012,307)$ I'm unsure what to make of this suggestion, but it might be an option for (PP).
} 


\section{Conclusion}

In this paper I have looked at numerous reasons those who hold (PNP) give for thinking God isn't a person. I have found most of them wanting, or at least insufficient to justify (PNP), and have suggested that the key debate is really over how one understands divine simplicity. If defenders of (PNP) disagree they are welcome to elaborate more fully as to how the other reasons they give for denying (PP) overcome what I have said here. If defenders of (PNP) retreat to the claim that all they meant was that by holding (PP), rather than (PNP), one is more likely to come up with a concept of God they find objectionable, e.g. isn't simple, is passible, temporal, etc., defenders of (PP) may wish to concede this point. Nonetheless, defenders of (PP) should also note that this is beside the point since it can be shown that (PP) is consistent with each of these claims, and further that if this was all (PNP) wished to defend then this is both a very weak claim and one they could have made a lot clearer from the outset. Given that I have offered no positive reasons for adopting (PP) in this paper, we can at present think both views are in an epistemically similar situation. ${ }^{46}$ Further exploration as to whether there are any good positive reasons for (PP), or any others for (PNP) and how both sides would respond will have to wait for another time. Yet, it might be that there are no good positive arguments for either view and as such we are left at an impasse. Given that I recommend what I hinted at earlier, namely that both parties fill out their conceptions of God to show how their conception overall is more coherent and fruitful. Through this we might learn which view is superior. For now, given the current literature, it seems to me that defenders of (PNP) have overstated their case, and at present the substantive debate lies in a relatively small area, over divine simplicity, rather than the numerous areas they suggested. $^{47}$

Acknowledgements The undertaking of this paper was inspired by the work of a former teacher, Brian Leftow, since he modelled perfectly how to think charitably about ancient and medieval philosophy, as well as how to synthesise this with contemporary insights. I also wish to thank Max Baker-Hytch and Greg Stacey for comments on an earlier draft.

Open Access This article is distributed under the terms of the Creative Commons Attribution 4.0 International License (http://creativecommons.org/licenses/by/4.0/), which permits unrestricted use, distribution, and reproduction in any medium, provided you give appropriate credit to the original author(s) and the source, provide a link to the Creative Commons license, and indicate if changes were made.

\footnotetext{
46 Pouivet $(2018,18)$ contends no good reasons for (PP) can be given. This can likely be questioned on perfect being grounds (Mawson 2019, 10; Leftow 2012, 196) and from thinking only persons can have some of the attributes we say God has (Leftow 2006, 372). How good these reasons are would need to be further explored.

47 Davies at one point seems to hint at something like this, when he writes, 'you should not assume that those who side with some of the tenets of ... [(PNP)] as I have outlined them also agree with all of them. Nor should you suppose that there is an easily identifiable body of ... [(PNP)] who all believe the same when it comes to the question 'What is God?' You should also not suppose that there is a solid body of thinkers calling themselves ... [(PP)] and all saying exactly the same thing when it comes to God's nature.' (2004, 16) As such perhaps Davies thinks (PP) is compatible with many things (PNP) claims. However, in his later writings he doesn't seem to make this concession, and neither do other proponents of (PNP).
} 


\section{References}

Adams, M. M. (1999). Horrendous evils and the goodness of god. Ithaca: Cornell University Press.

Aquinas, De Potentia Dei.

Aquinas, Summa Theologiae.

Aquinas, Super sent.

Baker, L. R. (2000). Persons and bodies: A constitution view. New York: Cambridge University Press. Boethius, Liber de persona et duabus naturis contra Eutychen et Nestorium.

Brower, J. E. (2008). Making sense of divine simplicity. Faith and Philosophy, 25, 3-30.

Brower, J. E. (2009). Simplicity and aseity. In T. Flint \& M. C. Rea (Eds.), The Oxford handbook of philosophical theology. New York: Oxford University Press.

Brower, J. E., \& Rea, M. C. (2005). Material constitution and the trinity. Faith and Philosophy, 22, 57-76.

Buckareff, A. A., \& Nagasawa, Y. (2016a). Alternative concepts of the divine: Essays on the metaphysics of the divine. New York: Oxford University Press.

Buckareff, A. A., \& Nagasawa, Y. (2016b). Introduction: Alternative conceptions of divinity and contemporary analytic philosophy of religion. In A. A. Buckareff \& Y. Nagasawa (Eds.), Alternative concepts of god. New York: Oxford University Press.

Chappell, T. (2011). On the very idea of criteria for personhood. The Southern Journal of Philosophy, $49,1-27$.

Craig, W. L. (1998a). Creation, providence and miracles. In B. Davies (Ed.), Philosophy of religion: A guide to the subject. Washington DC: Georgetown University Press.

Craig, W. L. (1998b). Creation and conservation once more. Religious Studies, 34, 177-188.

Craig, W. L. (1998c). Divine timelessness and personhood. International Journal for Philosophy of Religion, 43, 109-124.

Craig, W. L. (2001). Time and eternity. Illinois: Crossway.

Craig, W. L. (2012). On the goodness of god. https://www.reasonablefaith.org/writings/questionanswer/on-the-goodness-of-god. Accessed 14 Nov 2018.

Culpepper, G. (2009). "One suffering, in two natures": An analogical inquiry into divine and human suffering. In J. F. Keating \& T. J. White (Eds.), Divine impassibility and the mystery of human suffering. Grand Rapids: William B. Eerdmans.

Davies, B. (2004). An introduction to the philosophy of religion (3rd ed.). New York: Oxford University Press.

Davies, B. (2006). The reality of god and the problem of evil. London: Continuum.

Davies, B. (2011). Thomas aquinas on god and evil. New York: Oxford University Press.

Dennett, D. (1976). Conditions of personhood. In A. O. Rorty (Ed.), The identities of persons. Berkeley, CA: University of California Press.

Engelhardt, H. T. (1989). Ethical issues in aiding the death of young children. In R. M. Baird \& S. E. Rosenbaum (Eds.), Euthanasia: The moral issues. New York: Prometheus Books.

Feser, E. (2009). Aquinas. Oxford: Oneworld.

Feser, E. (2013). Craig on theistic personalism. http://edwardfeser.blogspot.co.uk/2013/04/craig-ontheistic-personalism.html. Accessed 14 Nov 2018.

Feser, E. (2017). Five proofs of the existence of god. San Francisco: Ignatius Press.

Harris, J. (1985). The value of life. London: Routledge.

Hart, D. B. (2013). The experience of god. New Haven: Yale University Press.

Hewitt, S. (2018). God is not a person (an argument via pantheism). International Journal for Philosophy of Religion. https://doi.org/10.1007/s11153-018-9678-x.

Jaworski, W. (2016). Structure and the metaphysics of mind: How hylomorphism solves the mind-body problem. New York: Oxford University Press.

Kvanvig, J. L. (2018). Anselmian adversities. Religious Studies. https://doi.org/10.1017/S003441251 8000604.

Kvanvig, J. L. (2019). Metatheology and the ontology of the divine. In S. Kittle (Ed.), Personal and apersonal conceptions of god. Cambridge: Cambridge University Press.

Leftow, B. (manuscript). Perfect being theology.

Leftow, B. (1990). Is god an abstract object? Noûs, 24, 581-598.

Leftow, B. (1991). Time and eternity. Ithaca: Cornell University Press. 
Leftow, B. (1999). Anti social trinitarianism. In S. Davis \& D. Kendall (Eds.), The trinity. New York: Oxford University Press.

Leftow, B. (2002). The eternal present. In G. E. Ganssle \& D. M. Woodruff (Eds.), God and time: Essays on the divine nature. New York: Oxford University Press.

Leftow, B. (2004a). A latin trinity. Faith and Philosophy, 21, 304-333.

Leftow, B. (2004b). Anselm's perfect-being theology. In B. Davies \& B. Leftow (Eds.), Cambridge companion to anselm. New York: Cambridge University Press.

Leftow, B. (2006). Divine simplicity. Faith and Philosophy, 23, 365-380.

Leftow, B. (2010). Two trinities: Reply to Hasker. Religious Studies, 46, 441-447.

Leftow, B. (2012). God and necessity. New York: Oxford University Press.

Leftow, B. (2013). God's deontic perfection. Res Philosophica, 90, 69-95.

Leftow, B. (2015). Concepts of god. In Routledge encyclopedia of philosophy. https://www.rep.routl edge.com/articles/thematic/god-concepts-of/v-2. Accessed 14 Nov 2018.

Leftow, B. (2016a). Naturalistic pantheism. In A. A. Buckareff \& Y. Nagasawa (Eds.), Alternative concepts of god. New York: Oxford University Press.

Leftow, B. (2016b). Divine simplicity and divine freedom. Proceedings of the American Catholic Philosophical Association, 89, 45-56.

Maitzen, S. (2017). Perfection, evil, and morality. In J. P. Sterba (Ed.), Ethics and the problem of evil. Bloomington: Indiana University Press.

Mander, W. J. (1997). God and personality. The Heythrop Journal, 38, 401-412.

Mawson, T. J. (2005). Belief in god: An introduction to the philosophy of religion. New York: Oxford University Press.

Mawson, T. J. (2019). The divine attributes. New York: Cambridge University Press.

McDaniel, K. (2017). The fragmentation of being. New York: Oxford University Press.

McMahan, J. (2002). The ethics of killing: Problems at the margins of life. New York: Oxford University Press.

Oderberg, D. S. (2000). Moral theory: A non-consequentialist approach. Oxford: Blackwell.

Oderberg, D. S. (2007). Real essentialism. New York: Routledge.

Oppy, G. (2014). Describing gods. Cambridge: Cambridge University Press.

Plantinga, A. (1980). Does god have a nature?. Milwaukee: Marquette University Press.

Plantinga, A. (2000). Warranted christian belief. New York: Oxford University Press.

Pouivet, R. (2018). Against theistic personalism: What modern epistemology does to classical theism. European Journal for Philosophy of Religion, 10, 1-19.

Pruss, A. R. (2006). The principle of sufficient reason: A reassessment. New York: Cambridge University Press.

Pruss, A. R. (2008). On two problems of divine simplicity. Oxford Studies in Philosophy of Religion, $1,150-167$.

Pruss, A. R. (2017). Person is not a natural kind. http://alexanderpruss.blogspot.co.uk/2017/04/perso n-is-not-natural-kind.html. Accessed 14 Nov 2018.

Quinn, P. L. (1983). Divine conservation, continuous creation, and human action. In A. J. Fredosso (Ed.), The existence and nature of god. Notre Dame: University of Notre Dame Press.

Quinn, P. L. (1988). Divine conservation, secondary causes, and occasionalism. In T. V. Morris (Ed.), Divine and human action. New York: Cornell University Press.

Quinn, P. (2006). Atonement and Kantian justification. In C. B. Miller (Ed.), Essays in philosophy of religion. New York: Oxford University Press.

Schaffer, J. (2009). On what grounds what. In D. Chalmers, D. Manley, \& R. Wasserman (Eds.), Metametaphysics. New York: Oxford University Press.

Schellenberg, J. L. (2016). God for all time: From theism to ultimism. In A. A. Buckareff \& Y. Nagasawa (Eds.), Alternative concepts of god. New York: Oxford University Press.

Singer, P. (2011). Practical ethics (3rd ed.). New York: Cambridge University Press.

Sorensen, R. (2015). Fictional theism. Analysis, 75, 539-550.

Stump, E. (2016). The god of the bible and the god of the philosophers. Milwaukee: Marquette University Press.

Stump, E., \& Kretzmann, N. (1985). Absolute simplicity. Faith and Philosophy, 2, 353-382.

Swinburne, R. (1994). A Christian god. New York: Oxford University Press.

Swinburne, R. (2016). The coherence of theism (2nd ed.). New York: Oxford University Press.

Swinburne, R. (2018). The social theory of the Trinity. Religious Studies, 54, 419-437.

Thatcher, A. (1985). The personal god and the God who is a person. Religious Studies, 21, 61-73. 
Tillich, P. (1955). Biblical religion and the search for ultimate reality. Chicago: University of Chicago Press.

Tooley, M. (1983). Abortion and infanticide. Oxford: Clarendon Press.

Vallicella, W. F. (2016). God, modality, and morality review. Faith and Philosophy, 33, 374-381.

Van Inwagen, P. (2006). The problem of evil. New York: Oxford University Press.

Warren, M. A. (1973). On the moral and legal status of abortion. The Monist, 57, 43-61.

Webb, C. C. J. (1919). God and personality. London: George Allen \& Unwin LTD.

Weinandy, T. G. (2000). Does god suffer?. Notre Dame: University of Notre Dame Press. 